\title{
Article \\ Can Grazing Moderate Climatic Effects on Herbage Nutritional Quality?
}

\author{
Guy Dovrat ${ }^{1, *}$, Efrat Sheffer ${ }^{2}$, Serge Yan Landau ${ }^{3}$, Tova Deutch ${ }^{3}$, Haim Gorelik ${ }^{1}$ and Zalmen Henkin ${ }^{1}$ \\ 1 Newe-Ya'ar Research Center, Department of Natural Resources, Agricultural Research Organization—Volcani \\ Institute, Ramat Yishay 30095, Israel; haimg@volcani.agri.gov.il (H.G.); henkinz@volcani.agri.gov.il (Z.H.) \\ 2 Institute of Plant Science and Genetics in Agriculture, The Robert H. Smith Faculty of Agriculture, Food and \\ Environment, The Hebrew University of Jerusalem, Rehovot 76101, Israel; efrat.sheffer@mail.huji.ac.il \\ 3 Department of Natural Resources, Agricultural Research Organization-Volcani Institute, \\ Bet-Dagan 50250, Israel; vclandau@volcani.agri.gov.il (S.Y.L.); tova.deutch@mail.huji.ac.il (T.D.) \\ * Correspondence: dovrat@volcani.agri.gov.il; Tel.: +972-49-539-559
}

Citation: Dovrat, G.; Sheffer, E.; Landau, S.Y.; Deutch, T.; Gorelik, H.; Henkin, Z. Can Grazing Moderate Climatic Effects on Herbage Nutritional Quality? Agronomy 2021, 11,700. https://doi.org/10.3390/ agronomy11040700

Academic Editor: Aiming Qi

Received: 12 March 2021

Accepted: 2 April 2021

Published: 7 April 2021

Publisher's Note: MDPI stays neutral with regard to jurisdictional claims in published maps and institutional affiliations.

Copyright: (c) 2021 by the authors. Licensee MDPI, Basel, Switzerland. This article is an open access article distributed under the terms and conditions of the Creative Commons Attribution (CC BY) license (https:// creativecommons.org/licenses/by/ $4.0 /)$.

\begin{abstract}
In Mediterranean grasslands, the composition of vegetation and its nutritional quality for animals are strongly affected by the climatic conditions prevailing during winter and spring. Therefore, these seasonal ecosystems provide an opportunity to examine how variability in climatic conditions affects the regeneration and quality of pasture vegetation. The intensity of grazing in this seasonal system can moderate, or alternatively exacerbate, climatic effects on the nutritional quality of the vegetation. Herein, we analyzed the interactive effects of climate variables, grazing intensity, and grazing exclusion on herbage quality parameters using long-term vegetation and climate data collected during 2005-2018 from an extensive experiment in Galilee, Israel. We evaluated the contribution of different climate variables to the prediction of herbage quality parameters. Our results showed that climate variables have a dramatic effect on herbage quality and that this effect interacts with grazing intensity. Herbage quality improved in temperate rainy years compared to warm and dry years. High grazing intensity improved herbage quality under temperate climate conditions, but this effect was moderated or completely disappeared as winter conditions become warmer and drier. The results of the study foresee negative effects of warming and drying on the carrying capacity of natural pastures.
\end{abstract}

Keywords: climate change; digestibility; grassland; grazing intensity; Mediterranean climate; pasture; protein

\section{Introduction}

Global climate change poses a challenge for predicting short- and long-term ecosystem functions, particularly with respect to estimating the services provided by ecosystems to humans [1,2] and predicting the threats expected from the increased sensitivity of these ecosystems [3,4]. In dry Mediterranean regions, the effects of warming and drying are most noticeable through extreme events such as fires and soil erosion [5,6]. Nevertheless, gradual changes in ecosystems, such as plant species turnover, drought-induced mortality, and dead biomass accumulation, can result in continuous changes in the supply of ecosystem services [2], which are provided by both natural and man-made systems. For example, in grazing pastures, the carrying capacity of the land is derived from the quantity and quality of the herbage [7], which is influenced by the composition and productivity of the vegetation.

Climate models predict that the Mediterranean region is expected to become warmer and drier [8]. Regional and global models predict an increase in temperature and a decrease in rainfall amounts, as well as increased frequency of extreme events [9-11]. The latter is expected to strongly influence vegetation composition and function [12,13]. Indeed, in recent decades, the climate in the eastern Mediterranean Basin has become more arid 
in most regions [14]. These expected climatic trends will have direct effects on plant physiology at the individual plant level [15-17] and on the composition and function of the vegetation at the plant community level $[18,19]$. Changes at the individual plant level include plastic changes in size and resource allocation, together with phenology-driven changes in the concentrations of resources in the plants throughout the year. Changes in vegetation composition include species turnover and shifts in the abundance and cover of plant species $[20,21]$.

The nutritional value of pasture vegetation as feed (herbage nutritional quality) is the foundation for domestic grazing, the most common agricultural use worldwide, which constitutes a large part of human-influenced ecosystems [22]. The abovementioned changes in vegetation may affect herbage quality and pasture productivity, and hence, the productivity and profitability of domestic grazing on natural pastures. Therefore, estimation of the extent of the effects of climate on the productivity of pasture vegetation and its quality as herbage are important for understanding the future of grazing, especially, but not exclusively, in drylands.

Mediterranean regions are characterized by a long, hot summer and a short, rainy winter with moderate temperatures. Mediterranean environments, therefore, foster a grazing system with an acutely seasonal pattern [23]. Thus, annual examination, over time, of climate cycles and variables and vegetation productivity and quality parameters may reveal long-term trends, as well as the extent of the effects of different climate variables and extreme events on pasture productivity and quality. As a general rule, the determination of the carrying capacity of pastures usually focuses on the annual/seasonal productivity of the vegetation with respect to the grazing intensity of the livestock [24]. Many studies have focused on the effects of the quantity and distribution of rainfall on productivity [12,25], but few studies have focused on the effects of climate on the nutritional quality of the vegetation under grazing [26], even though this is a key component determining livestock consumption [27].

Some studies in Mediterranean climate regions have reported a decrease in herbage nutritional quality during the short winter and spring period, sometimes in late spring [23] or early summer $[28,29]$. Others have focused on continuous changes and demonstrated a limited effect of grazing intensity, together with a positive seasonal effect of grazing during winter and spring $[29,30]$. However, studying the effect of grazing is complex because grazing intensity plays a double role in its influence on herbage quality; an increase in grazing intensity increases herbage quality through accelerated regeneration of the vegetation, while in contrast, high grazing intensity in the long term may displace palatable species and promote the growth of mechanically and chemically protected species (e.g., plants with thorns and prickles or toxins [31]) potentially also with lower nutritional quality. One way to deal with this complexity is through long-term grazing experiments that include different grazing intensities and ungrazed controls, as we present herein.

Despite the known effects of pasture legacy and the soil seed bank in shaping the composition of vegetation in seasonal herbaceous systems [32], climatic conditions during the wet season have a formative effect on the quality of the herbaceous vegetation [33]. The prevailing assumption is that a cool, wet year leads to high-quality pasture because individual plants will be large and the community will be dominated by species with rapid growth rates and low tissue densities [34]. Conversely, high availability of resources (water and soluble macro- and micro-nutrients) will lead to plant-plant competition and result in the displacement of species such as legumes and short grasses with high nutritional quality [35] by tall plants with high investment in vegetative tissues [36], which may increase the concentration of fiber in the pasture and therefore reduce its quality.

In light of all the above, we hypothesized that (1) herbage nutritional quality will improve in cool, rainy years and decline in warm, dry years, and (2) high grazing intensity will improve herbage quality and mitigate climatic effects on herbage quality.

In recent decades, near-infrared spectroscopy (NIRS) has been developed as a rapid, large-scale, inexpensive method to determine the nutritional composition of feeds [37] 
and has been used for long-term determination of herbage quality at the Karei Deshe Experimental Range Station in eastern Galilee. Using a unique, multi-year (2005-2018) data set of herbage quality and meteorological data, we examined the effects of different annual and seasonal climate variables on different parameters that define the nutritional quality of vegetation. We tested the interactive effect of climate variables and varying levels of grazing intensity. This study examined the following specific questions: (1) To what extent do different climate variables influence herbage quality parameters in a water-limited environment? (2) Does grazing mitigate the negative influence of climate on the nutritional quality of herbage?

\section{Materials and Methods}

\subsection{Study Site}

This research was carried out at the Karei Deshe Experimental Range Station in the northeastern Galilee region of Israel $\left(32^{\circ} 55^{\prime} \mathrm{N}, 35^{\circ} 35^{\prime} \mathrm{E}\right)$. The topography is hilly, covered with basaltic rocks with an average cover of $30 \%$ [38]. The soil is brown basaltic protogrumusol. The vegetation is classified as Mediterranean Batha, dominated by grasses and forbs. The dominant perennial species are the hemicryptophytes Bituminaria bituminosa (L.) Stirt., Echinops gaillardotii Boiss., E. adenocaulos Boiss., Ferula communis L., and Hordeum bulbosum L., which form approximately $30 \%$ of the plant cover [38,39]. Most other species are herbaceous annuals, including grasses (Avena sterilis L., Alopecurus utriculatus Sol., and Bromus spp.), legumes (Medicago spp. and Trifolium spp.), composites, crucifers, and umbellifers. Growth and development of the vegetation strongly depends on the climatic conditions prevailing during the short winter-spring growing season from late October/mid-November to late April/early May. The mean annual rainfall is $551 \mathrm{~mm}$. During the summer, the vegetation dries out.

\subsection{Experimental Treatments}

A long-term study was established at the station in 1994 with eight paddocks grazed by cattle under controlled grazing intensities [40]. The four experimental treatments used for our analysis included three grazing intensity treatments—very heavy $\left(2.2\right.$ cows ha $\left.^{-1}\right)$, heavy ( 1.1 cows ha $\left.{ }^{-1}\right)$, and moderate $\left(0.55\right.$ cows ha $\left.^{-1}\right)$-and a grazing exclusion control treatment. Each treatment was replicated twice. Paddocks were stocked annually with adult, crossbred Simmental cows; these cows usually graze for approximately eight months per year, from mid-January to late September. Deferment of grazing after the onset of the rainy season in late autumn allows establishment and early growth of the pasture [29]. The grazing treatments have been maintained without change since 1994.

Climate data, including hourly temperature and humidity and daily rainfall, were collected by an on-site meteorological station. We analyzed the effects of nine average daily, monthly, and seasonal climate variables, and extreme values, including total seasonal rainfall amount (until the date of vegetation sampling, $\mathrm{mm}$ ), accumulated rainfall amounts $(\mathrm{mm})$, and proportions (i.e., percentages of the total seasonal rainfall) in December and April, as well as maximum and minimum temperatures $\left({ }^{\circ} \mathrm{C}\right)$ and relative air humidity (\%), measured daily between October and April. Long-term variation in all nine climate variables along the 14 experimental years is presented in Figure S1.

Most of the nine climate variables were correlated to one another. All of the relative humidity and temperature variables were correlated, at different levels of significance, to all of the other variables. Only a few correlations were not significant, including December rain vs. total rain until sampling, December rain vs. April rain, and the same correlations including December and April rainfall proportions.

\subsection{Vegetation Sampling}

Vegetation sampling took place every year from 2005 to 2018 (14 years) in spring (April), at the peak of vegetation growth. Quadrats of $25 \times 25 \mathrm{~cm}$ were randomly placed along permanent transects in each paddock. All aboveground herbaceous standing biomass 
within each quadrat was harvested. Twenty samples were harvested per paddock per season, resulting in a total of 160 samples for each year of the study. The harvested samples were oven-dried at $65^{\circ} \mathrm{C}$ for three days and then weighed and ground for analysis. Each year, samples from each paddock were pooled into three replicates and their nutritional quality was analyzed using NIRS calibrated upon wet chemistry [37] (total of 336 measurements per nutritional parameter). The nutritional parameters measured included in vitro dry matter digestibility (IVDMD [41]), crude protein (CP) concentration (automated Kjeldahl, method 976.05 [42]), dietary fiber attributes of neutral detergent fiber (NDF; with alpha-amylase), acid detergent fiber (ADF) [43], and ash content. Reference values for NIRS equations (Table S1) were determined using herbage samples (ca. 360 in total) collected during all seasons. While elevated values of IVDMD and $\mathrm{CP}$ indicate an increase in herbage nutritional quality of the pasture, high values of $\mathrm{NDF}, \mathrm{ADF}$, and ash content indicate a decrease in herbage nutritional quality.

\subsection{Data Analysis}

We used maximum likelihood analysis to analyze whether, and how, the grazing treatments and the various climate variables affected each of the five herbage nutritional parameters. We tested additive and multiplicative linear models with the effects of one of the nine climate variables (as a continuous factor), four grazing treatments (as a categorical factor), their interaction, and a constant intercept, as follows:

$$
\begin{gathered}
\text { Multiplicative model: } Y_{i j}=a+b_{i} X_{j} \\
\text { Linear model: } Y_{i j}=a+b_{i}+c X_{j}
\end{gathered}
$$

where $Y_{i j}$ is the nutritional quality variable from each grazing treatment $i$ and year $j, a$ is the intercept, $b$ and $c$ are the linear slope parameters, where $b_{i}$ is the slope for each grazing treatment, and $X_{j}$ is the climate variable in year $j$.

Additional models tested the mean effect of each of the grazing treatments without the climate variable, i.e., using ANOVA-like maximum likelihood analysis. We compared the complete set of models, each time with a different climate variable, for each nutritional parameter. We used the Akaike information criterion corrected for a small sample size (AICc) to compare the strength of evidence for competing alternative models for each nutritional parameter. We solved the maximum likelihood parameter values for each model in our set of models using simulated annealing in the "likelihood 1.3" package in $\mathrm{R}$ [44]. Residuals $(\varepsilon)$ for the different variables were normally distributed, so the error terms were modeled accordingly. We used asymptotic two-unit support intervals to assess the strength of evidence for individual maximum likelihood parameter estimates [45]. To evaluate each alternative model, we calculated the slope and the $R^{2}$ of the regression of observed vs. predicted values, as measures of model bias and goodness-of-fit, respectively. Statistical analyses were performed in the $R$ programming environment version 2.8 .0 ( $R$ Development Core Team, 2008, for maximum likelihood analysis). Correlations between the nine climate variables were performed using the Pearson's correlation index, in SPSS v.25.0 software (SPSS Inc., Chicago, IL, USA).

\section{Results}

Climate variables demonstrated a significant, interactive effect with grazing intensity on herbage quality. Cool, rainy years were associated with improved herbage quality according to most of the tested nutritional parameters (Figure 1). The models that included the effect of maximum daily temperature in winter combined with grazing treatments were most parsimonious for NDF $\left(R^{2}=0.40\right)$, crude protein content $\left(R^{2}=0.44\right)$, and digestibility $\left(R^{2}=0.33\right)$ of the vegetation (Tables S2-S5). These models showed that the NDF content increased and the crude protein content and digestibility decreased with increasing winter temperatures (Figures $1 \mathrm{a}, \mathrm{c}$ and 2 ) and that heavy grazing intensity improved the nutritional quality attributes in cool years (i.e., lower NDF and fiber contents 
and higher crude protein content and digestibility); however, the positive effect T of heavy grazing decreased or disappeared completely in warm, dry years (Figures 1 and 2). Thus, for example, the herbage crude protein content increased under heavy and very heavy grazing intensities in years with low temperatures and high rainfall and humidity; this interactive effect of grazing intensity and climate variables on crude protein content showed a moderation of the grazing effect at high temperatures (Figure 1a). Regarding crude protein content, these trends were repeated in the models for all of the tested climate variables (Table S4), including extreme climate variables (using average daily values of these variables). Nevertheless, the interaction between winter daily maximum temperature (the best predictor) and grazing did not improve the predictability of the NDF content or digestibility; rather, the models without the interaction were the most parsimonious (Table S2).
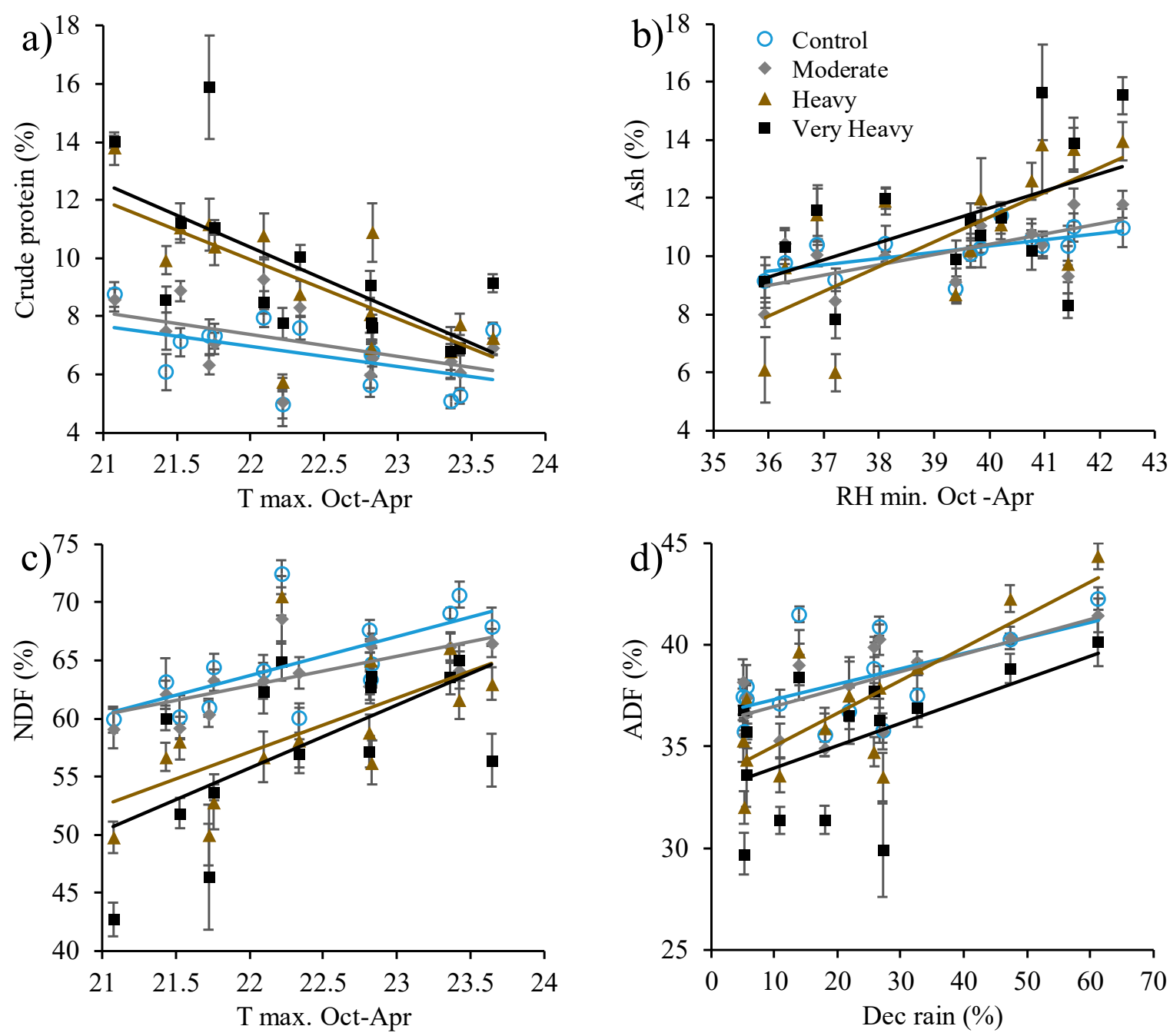

Figure 1. Relationships between the climate variables and mean nutritional parameters values under four grazing intensities. (a) Crude protein content in herbage (\%) and winter daily maximum temperature, (b) herbage ash content (\%) and winter daily minimum relative humidity, (c) herbage NDF (neutral detergent fiber) content (\%) and winter daily maximum temperature, and (d) herbage ADF (acid detergent fiber) content (\%) and the proportion of annual rain in December. The climate variables presented in the graphs provided the most parsimonious model among the nine different climate variables tested. Data were collected annually at the Karei Deshe Experimental Station. Each point represents the average of six pooled samples (of $n=6-8$ samples each). The solid trend lines are significant at $p \leq 0.05$. 


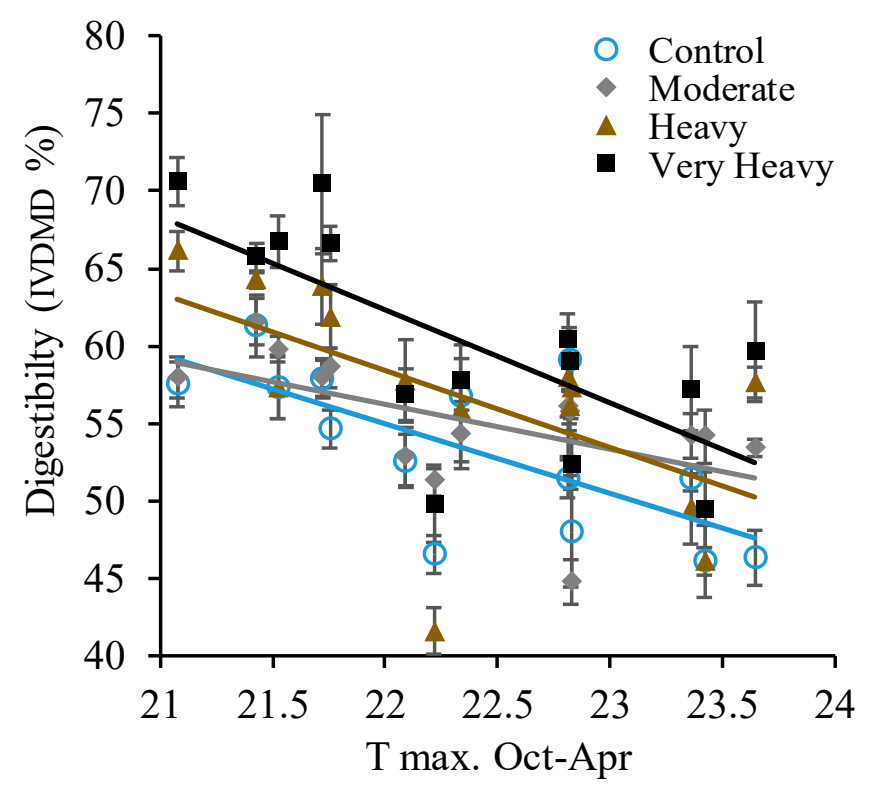

Figure 2. Relationship between the winter daily maximum temperature and in vitro dry matter digestibility (IVDMD) of herbage (\%) under four grazing intensities. The winter daily maximum temperature was found to be the best predictor among the nine different climate variables tested. Data were collected annually at the Karei Deshe Experimental Range Station. Each point represents the average of six pooled samples (of six to eight samples each). The solid trend lines are significant at $p \leq 0.05$.

The increased NDF content means a decrease in herbage quality. The average NDF content in the ungrazed control and moderate grazing intensity paddocks ranged from $60 \%$ in cool years to $68 \%$ in warm years. In contrast, at heavy and very heavy grazing intensities, NDF content ranged from $52 \%$ in cool years to $63 \%$ in warm years (Figure 1c). The average crude protein content in the ungrazed control and moderate grazing intensity paddocks ranged from $8 \%$ in cool years to $6 \%$ in warm years (Figure 1a). Conversely, at heavy and very heavy grazing intensities, the crude protein content ranged from $11 \%$ in cool years to $7 \%$ in warm years. These differences were observed across a range of $2.5^{\circ} \mathrm{C}$ in daily maximum temperature, and a range of $2{ }^{\circ} \mathrm{C}$ in daily minimum temperature, measured during the winter months (Figure S1).

The models that included daily minimum humidity and the proportion of annual rainfall in December (percent rainfall in December), together with grazing, demonstrated the second- and third-best predictive ability, respectively, in their effect on the NDF and crude protein contents $\left(\Delta \mathrm{AIC}_{\mathrm{NDF}}=37.4-40, \Delta \mathrm{AIC}_{\text {protein }}=41.7-51\right.$ respectively, Tables S3 and S4). The effects of the total amount of rainfall (until the date of vegetation sampling) on the NDF and crude protein contents were significant, but this was only the sixth-best predictor of NDF content $(\triangle \mathrm{AIC} C=91.7)$ and the seventh-best predictor of crude protein content $(\triangle \mathrm{AICc}=95.2$; out of nine climate variables $)$.

In contrast to the NDF content, the most parsimonious model for the ADF content included the proportion of total rainfall shed in December (early winter-the germination period), together with grazing intensity $\left(R^{2}=0.35\right.$, Table S6). We found that the ADF content increased with an increasing proportion of rain in December (Figure 1d). This climate variable expresses early-season resource availability, but even more so, it is a good measure of the distribution and amount of rainfall throughout the rest of the season. In the control and moderately grazed paddocks, the ADF content ranged from $36 \%$ in dry years to $41 \%$ in years, in which a large proportion of the rain fell in December. In the heavy and very heavily grazed paddocks, the ADF content was similar and relatively low in dry years $(33 \%-34 \%)$, but in wet years, the ADF content under heavy grazing was similar to that of the control vegetation ( $43 \%$ and $44 \%$, respectively), while very heavy grazing reduced ADF 
to $39 \%$. These values were observed under December rainfall proportions ranging from $5 \%$ to $65 \%$ of the total rainfall amount. The model that included the daily maximum winter temperature, together with grazing treatments, showed the second-best predictive ability for ADF. The amount of rain in December (early-season availability) was the third-best predictor (Table S6).

Exceptional among the parameters was the ash content of the vegetation, which increased with the amount of rain and humidity and decreased with temperature. In other words, the ash content did not demonstrate a trend of improved nutritional value of the vegetation under temperate conditions. The most parsimonious model for ash content included the interactive effects of the minimum humidity in winter and grazing treatments $\left(\mathrm{R}^{2}=0.26\right)$ (Figure $1 \mathrm{~b}$ and Table $\mathrm{S7}$ ). The second-best predictor was maximum humidity and total rain until sampling date, together with grazing intensity. The average ash content in the control and moderately grazed paddocks ranged from $9 \%$ in years with the lowest average minimum humidity to $11 \%$ in more humid years. In contrast, in the heavily and very heavily grazed paddocks, the ash content ranged from $8 \%$ to $9 \%$ in years with low average minimum humidity to $13 \%$ in more humid years. These differences were observed across a $6 \%$ range in minimum daily humidity values measured during the winter months. Nutritional parameters and climate data are presented in Table S8.

\section{Discussion}

For most of the tested vegetation quality parameters, moderate climate conditions, i.e., cool years, improved the nutritional quality of the pasture, and notably its digestibility. We showed, in a seasonal Mediterranean environment, that during the short, winter-spring growing season, heavy grazing intensity improved herbage nutritional quality parameters, but this occurred only during years with temperate climate conditions, and this positive effect was moderated or disappeared completely during hot, dry years.

The amount and distribution of rainfall are considered to be the primary factors shaping forage productivity [12,25] and quality [33] in water-limited environments. With respect to productivity, these effects are known, and have been shown in previous studies [32,46]; however, the effects on herbage quality are less known [47]. The amount of rainfall accumulated until the time of pasture sampling, and other variables related to the distribution of rainfall within the growing season, had a significant effect on all of the nutritional quality parameters; for all nutritional parameters, the effects of grazing and interaction between rainfall and grazing showed improved predictive power. Nevertheless, we found that other climate variables were more sensitive and better predictors of herbage quality parameters, particularly the daily maximum temperature and daily minimum humidity during the growing season (October-April). While most of the tested climate variables were intercorrelated (and therefore, we could not test the climate variables concurrently), we found large differences in their predictive power. Both humidity and temperature were better predictors (than rainfall variables) for the conditions during the short growing season and, therefore, for the conditions during the period of plant development, while rainfall was scattered throughout this period and had a lesser effect. The maximum temperature from October to April was found to be the best predictor of the crude protein content, the NDF content, and the digestibility of the vegetation.

In fact, the only nutritional parameter that was greatly affected by rainfall was ADF, which increased with increasing proportions of rain in December. This finding is related to the availability of plant resources at the beginning of the season, rather than the relative distribution of the water resource. The ADF content of pasture herbage is affected by the size of the plants and their developmental stage or maturity [48]; thus, plant growth is accelerated when much of the annual rainfall occurs early in the season (i.e., December), particularly in grasslands, which include many perennial plant species.

Under temperate conditions, our analysis showed differences in the effects of the two heavy grazing treatments on herbage ADF; very heavy grazing intensity improved and reduced the $\mathrm{ADF}$ content by fostering regeneration of the vegetation later in the 
season. In contrast, heavy grazing increased the ADF content, probably by accelerating the maturation of the vegetation that was damaged by grazing but was able to regrow under cattle consumption (Figure 1d).

In contrast to other herbage nutritional quality parameters, which improved in temperate years, the ash content presented an opposite trend, increasing under temperate conditions. The explanation for this probably lies in the concomitant increase in ash content with plant size in herbaceous plants. As for other plant parameters, the effect of grazing intensity on the ash content was significant only during temperate years, but in contrast to the other parameters, this effect was not beneficial; heavy or very heavy grazing intensity led to a higher ash content, which decreased the nutritional quality. Relatively high ash contents under grazing can be partly explained by the high frequency of perennial herbaceous components [49] in such plant communities, which contain a high ash content in the basal parts of the plants. It is important to note that plant ash also contains many of the minerals that are needed for livestock nutrition, and therefore its nutritional classification as beneficial or harmful is context-dependent.

Heavy and very heavy grazing intensity increased herbage quality during the short growing season; this result was noticeable for all of the nutritional parameters except for the ash content. Intensive grazing leads to an increase in the rate of regeneration of the vegetation and, therefore, to a high proportion of "young" vegetative parts in the vegetation, proportional to the grazing intensity. This means that with respect to herbage quality, the short-term beneficial effect of grazing, related to the regeneration rate of the vegetation under grazing, overrides the long-term effect of grazing intensity, which is expressed by changes in the vegetation composition [39,50] and structure [32] of the pasture. However, our results showed that the beneficial effect of grazing on herbage quality takes effect only during climatically humid years with moderate temperatures and disappears or is moderated during dry and drought years when the growing season is shorter than average and, therefore, vegetative production decreases.

The known, long-term effects of grazing intensity on the composition and palatability of the vegetation [35] and its conceivable effect on herbage quality [13] were not expressed in our measurements, or were masked by the regenerative effect induced by the grazing itself. Nevertheless, the reason for this may lie in the long-term measurement method at the Karei Deshe site, which focuses on annual herbage productivity and quality and does not include perennial components such as woody plants and large spiny species that are not eaten by the cattle.

Although the moderate grazing intensities in this experiment were authentic (i.e., they are used by farmers in the region), we found a high similarity between paddocks with moderate grazing intensity and paddocks without grazing for all tested parameters (Figure 1), indicating a limited effect of moderate grazing on the vegetation. In Mediterranean grazing pastures, which have been grazed for thousands of years [51], the herbaceous vegetation is adapted to regeneration and development under grazing conditions. The two high grazing intensities were also similar to one another in their effect, despite the two-fold difference in intensity between them; nevertheless, with respect to vegetation digestibility, we observed a gradual effect of heavy and very heavy grazing on this parameter, which increased with grazing intensity.

\section{Conclusions}

The long-term results of this study can be used to estimate the quality of herbaceous pastures with respect to climatic conditions, but more importantly, our results showed trends that are expected to continue with ongoing climate change, which are expressed particularly strongly in Mediterranean regions [52]. An increase of $2.5{ }^{\circ} \mathrm{C}$ during the winter months, as expressed by the extreme measurements (maximum and minimum temperatures), reduced the crude protein content of the herbage at flowering time by $5 \%$ and increased the fiber content by ca. 10\%. The significance of this trend is that global warming, over time, will lead to reductions in herbage quality and, consequently, 
to a reduction in the carrying capacity of the pasture. Previous studies have shown that vegetation communities in these regions, with a long grazing history, are adapted to interannual changes in the amount of rainfall in winter [53]. However, trends of warming and decreased humidity are expected to shorten the growing season of the ephemeral herbaceous vegetation, which agricultural systems rely on throughout the year. The presence of grazing during the growing season, even at very high intensities, does not moderate the effect of climate warming on the nutritional quality parameters of grazed vegetation. However, we showed that a beneficial effect of grazing intensity on herbage quality during the growing season does exist, as demonstrated for Mediterranean systems in previous studies [33]. Nevertheless, this effect fades out during warmer, drier years; therefore, in future warming scenarios, grazing intensity in herbaceous vegetation will not suffice as a management tool to mitigate climatic effects.

Supplementary Materials: The following are available online at https:/ / www.mdpi.com/article/10 .3390 /agronomy11040700/s1, Figure S1: Climate data measured at the Karei Deshe Experimental Range Station during the research period, 2005-2018. Table S1: Calibration performance of the near-infrared spectroscopy (NIRS) equations for herbage nutritional composition. Table S2: Results of the most parsimonious models for each of the five nutritional parameters. Tables S3-S7: Comparison of models that test the effects of grazing intensity treatments and climate variables on herbage nutritional quality parameters. Table S8: Data.

Author Contributions: Conceptualization, G.D.; methodology, G.D., E.S. and S.Y.L.; formal analysis, G.D. and E.S.; investigation, Z.H., T.D. and H.G.; resources, S.Y.L., Z.H. and H.G.; writing-original draft preparation, G.D.; writing-review and editing, G.D., E.S., S.Y.L. and Z.H.; project administration, H.G. All authors have read and agreed to the published version of the manuscript.

Funding: This research received no external funding.

Data Availability Statement: Data available online at https://www.mdpi.com/article/10.3390/ agronomy11040700/s1, “Supporting information” Table S8.

Acknowledgments: The authors are greatly indebted to Yehuda Yehuda for his contribution to data collection for the study and the work at the Karei Deshe Experimental Range Station.

Conflicts of Interest: The authors declare no conflict of interest.

\section{References}

1. Chapin, F.S., III; Zavaleta, E.S.; Eviner, V.T.; Naylor, R.L.; Vitousek, P.M.; Reynolds, H.L.; Hooper, D.U.; Lavorel, S.; Sala, O.E.; Hobbie, S.E.; et al. Consequences of changing biodiversity. Nature 2000, 405, 234-242. [CrossRef] [PubMed]

2. Boone, R.B.; Conant, R.T.; Sircely, J.; Thornton, P.K.; Herrero, M. Climate change impacts on selected global rangeland ecosystem services. Glob. Chang. Biol. 2018, 24, 1382-1393. [CrossRef]

3. Young, A.M.; Higuera, P.E.; Duffy, P.A.; Hu, F.S. Climatic thresholds shape northern high-latitude fire regimes and imply vulnerability to future climate change. Ecography 2017, 40, 606-617. [CrossRef]

4. Lefebvre, G.; Redmond, L.; Germain, C.; Palazzi, E.; Terzago, S.; Willm, L.; Poulin, B. Predicting the vulnerability of seasonallyflooded wetlands to climate change across the Mediterranean Basin. Sci. Total Environ. 2019, 692, 546-555. [CrossRef] [PubMed]

5. Mouillot, F.; Rambal, S.; Joffre, R. Simulating climate change impacts on fire frequency and vegetation dynamics in a Mediterranean-type ecosystem. Glob. Chang. Biol. 2002, 8, 423-437. [CrossRef]

6. Batllori, E.; Parisien, M.; Krawchuk, M.A.; Moritz, M.A. Climate change-induced shifts in fire for Mediterranean ecosystems. Glob. Ecol. Biogeogr. 2013, 22, 1118-1129. [CrossRef]

7. Golluscio, R.A.; Bottaro, H.S.; Oesterheld, M. Controls of carrying capacity: Degradation, primary production, and forage quality effects in a Patagonian steppe. Rangel. Ecol. Manag. 2015, 68, 266-275. [CrossRef]

8. IPCC. The Intergovernmental Panel on Climate Change Special Report; Special Report on Climate Change, Desertification, Land Degradation, Sustainable Land Management, Food Security, and Greenhouse Gas Fluxes in Terrestrial Ecosystems; IPCC: Geneva, Switzerland, 2019.

9. Kelly, A.E.; Goulden, M.L. Rapid shifts in plant distribution with recent climate change. Proc. Natl. Acad. Sci. USA 2008, 105, 11823-11826. [CrossRef]

10. Black, E. The impact of climate change on daily precipitation statistics in Jordan and Israel. Atmos. Sci. Lett. 2009, 10, 192-200. [CrossRef]

11. Turco, M.; Levin, N.; Tessler, N.; Saaroni, H. Recent changes and relations among drought, vegetation and wildfires in the Eastern Mediterranean: The case of Israel. Glob. Planet. Chang. 2017, 151, 28-35. [CrossRef] 
12. Golodets, C.; Sternberg, M.; Kigel, J.; Boeken, B.; Henkin, Z.; Seligman, N.G.; Ungar, E.D. From desert to Mediterranean rangelands: Will increasing drought and inter-annual rainfall variability affect herbaceous annual primary productivity? Clim. Chang. 2013, 119, 785-798. [CrossRef]

13. Schaub, S.; Finger, R.; Leiber, F.; Probst, S.; Kreuzer, M.; Weigelt, A.; Buchmann, N.; Scherer-Lorenzen, M. Plant diversity effects on forage quality, yield and revenues of semi-natural grasslands. Nat. Commun. 2020, 11, 1-11. [CrossRef]

14. Kafle, H.K.; Bruins, H.J. Climatic trends in Israel 1970-2002: Warmer and increasing aridity inland. Clim. Chang. 2009, 96, 63-77. [CrossRef]

15. Allen, C.D.; Macalady, A.K.; Chenchouni, H.; Bachelet, D.; McDowell, N.; Vennetier, M.; Kitzberger, T.; Rigling, A.; Breshears, D.D. A global overview of drought and heat-induced tree mortality reveals emerging climate change risks for forests. For. Ecol. Manag. 2010, 259, 660-684. [CrossRef]

16. Adams, H.D.; Zeppel, M.J.; Anderegg, W.R.; Hartmann, H.; Landhäusser, S.M.; Tissue, D.T.; Huxman, T.E.; Hudson, P.J.; Franz, T.E.; Allen, C.D.; et al. A multi-species synthesis of physiological mechanisms in drought-induced tree mortality. Nat. Ecol. Evol. 2017, 1, 1285-1291. [CrossRef] [PubMed]

17. Dovrat, G.; Meron, E.; Shachak, M.; Golodets, C.; Osem, Y. Plant size is related to biomass partitioning and stress resistance in water-limited annual plant communities. J. Arid Environ. 2019, 165, 1-9. [CrossRef]

18. De Dato, G.; Pellizzaro, G.; Cesaraccio, C.; Sirca, C.; De Angelis, P.; Duce, P.; Spano, D.; Scarascia, M.G. Effects of warmer and drier climate conditions on plant composition and biomass production in a Mediterranean shrubland community. For. Ecol. 2008, 3, 511-526. [CrossRef]

19. Köchy, M.; Mathaj, M.; Jeltsch, F.; Malkinson, D. Resilience of stocking capacity to changing climate in arid to Mediterranean landscapes. Reg. Environ. Chang. 2008, 8, 73-87. [CrossRef]

20. McGill, B.J.; Etienne, R.S.; Gray, J.S.; Alonso, D.; Anderson, M.J.; Benecha, H.K.; Dornelas, M.; Enquist, B.J.; Green, J.L.; He, F.; et al. Species abundance distributions: Moving beyond single prediction theories to integration within an ecological framework. Ecol. Lett. 2007, 10, 995-1015. [CrossRef]

21. Le Roux, P.C.; McGeoch, M.A. Rapid range expansion and community reorganization in response to warming. Glob. Chang. Biol. 2008, 14, 2950-2962. [CrossRef]

22. Ellis, E.C.; Klein, G.K.; Siebert, S.; Lightman, D.; Ramankutty, N. Anthropogenic transformation of the biomes, 1700 to 2000. Glob. Ecol. Biogeogr. 2010, 19, 589-606. [CrossRef]

23. Landau, S.Y.; Dvash, L.; Yehuda, Y.; Muklada, H.; Peleg, G.; Henkin, Z.; Voet, H.; Ungar, E.D. Impact of animal density on cattle nutrition in dry Mediterranean rangelands: A faecal NIRS-aided study. Animal 2018, 12, 265-274. [CrossRef]

24. Ungar, E.D. Perspectives on the concept of rangeland carrying capacity, and their exploration by means of Noy-Meir's twofunction model. Agric. Syst. 2019, 173, 403-413. [CrossRef]

25. Miranda, J.D.; Armas, C.; Padilla, F.M.; Pugnaire, F.I. Climatic change and rainfall patterns: Effects on semi-arid plant communities of the Iberian Southeast. J. Arid Environ. 2011, 75, 1302-1309. [CrossRef]

26. Klein, J.A.; Harte, J.; Zhao, X. Experimental warming, not grazing, decreases rangeland quality on the Tibetan Plateau. Ecol. Appl. 2007, 17, 541-557. [CrossRef] [PubMed]

27. Osoro, K.; Ferreira, L.; García, U.; Martínez, A.; Celaya, R. Forage intake, digestibility and performance of cattle, horses, sheep and goats grazing together on an improved heathland. Anim. Prod. Sci. 2017, 57, 102-109. [CrossRef]

28. George, M.; Nader, G.; Dunbar, J. Balancing Beef Cow Nutrient Requirements and Seasonal Forage Quality on Annual Rangeland; Division of Agriculture and Natural Resources, University of California: Oakland, CA, USA, 2001.

29. Henkin, Z.; Landau, S.; Ungar, E.; Perevolotsky, A.; Yehuda, Y.; Sternberg, M. Effect of timing and intensity of grazing on the herbage quality of a Mediterranean rangeland. J. Anim. Feed Sci. 2007, 16, 318-322. [CrossRef]

30. Smart, A.J.; Derner, J.D.; Hendrickson, J.R.; Gillen, R.L.; Dunn, B.H.; Mousel, E.M.; Johnson, P.S.; Gates, R.N.; Sedivec, K.K.; Harmoney, K.R.; et al. Effects of grazing pressure on efficiency of grazing on North American Great Plains rangelands. Rangel. Ecol. Manag. 2010, 63, 397-406. [CrossRef]

31. Hanley, M.E.; Lamont, B.B.; Fairbanks, M.M.; Rafferty, C.M. Plant structural traits and their role in anti-herbivore defense. Perspect. Plant Ecol. Evol. Syst. 2007, 8, 157-178. [CrossRef]

32. Dovrat, G.; Meron, E.; Shachak, M.; Golodets, C.; Osem, Y. Functional reorganization and productivity of a water-limited annual plant community. Plant Ecol. 2020, 221, 191-204. [CrossRef]

33. Henkin, Z.; Ungar, E.D.; Dvash, L.; Perevolotsky, A.; Yehuda, Y.; Sternberg, M.; Voet, H.; Landau, S.Y. Effects of cattle grazing on herbage quality in a herbaceous Mediterranean rangeland. Grass Forage Sci. 2011, 66, 516-525. [CrossRef]

34. Ryser, P. The importance of tissue density for growth and life span of leaves and roots: A comparison of five ecologically contrasting grasses. Funct. Ecol. 1996, 1, 717-723. [CrossRef]

35. Diaz, S.; Lavorel, S.; McIntyre, S.U.E.; Falczuk, V.; Casanoves, F.; Milchunas, D.G.; Skarpe, C.; Rusch, G.; Sternberg, M.; Landsberg, J.; et al. Plant trait responses to grazing-a global synthesis. Glob. Chang. Biol. 2007, 13, 313-341. [CrossRef]

36. Dovrat, G.; Meron, E.; Shachak, M.; Golodets, C.; Osem, Y. The relative contributions of functional diversity and functional identity to ecosystem function in water-limited environments. J. Veg. Sci. 2019, 30, 427-437. [CrossRef]

37. Landau, S.Y.; Glasser, T.; Dvash, L. Monitoring nutrition in small ruminants with the aid of near infrared reflectance spectroscopy (NIRS) technology: A review. Small Rumin. Res. 2006, 61, 1-11. [CrossRef] 
38. Gutman, M.; Seligman, N.G. Grazing management of Mediterranean foothill range in the upper Jordan River valley. J. Range Manag. 1979, 32, 86-92. [CrossRef]

39. Sternberg, M.; Gutman, M.; Perevolotsky, A.; Ungar, E.; Kigel, J. Vegetation response to grazing management in a Mediterranean herbaceous community: A functional group approach. J. Appl. Ecol. 2000, 37, 224-237. [CrossRef]

40. Henkin, Z.; Ungar, E.D.; Perevolotsky, A.; Gutman, M.; Yehuda, Y.; Dolev, A.; Landau, S.Y.; Sternberg, M.; Seligman, N.G. Long-term trade-offs between herbage growth, animal production and supplementary feeding in heavily grazed Mediterranean grassland. Rangel. Ecol. Manag. 2015, 68, 332-340. [CrossRef]

41. Tilley, J.M.; Terry, R.A. A two-stage technique for the in vitro digestion of forage crops. Grass Forage Sci. 1963, 18, $104-111$. [CrossRef]

42. Cunniff, P. Official Methods of Analysis of AOAC International, 16th ed.; AOAC International: Arlington, VA, USA, 1995 ; Volume 1.

43. Goering, H.K.; Van Soest, P.J. Forage Fiber Analyses, Apparatus, Reagents, Procedures, and Some Applications. Agriculture Handbook; No. 379; ARS-USDA: Washington, DC, USA, 1970.

44. Murphy, L. Likelihood: Methods for Maximum Likelihood Estimation, R Package. Version 1.4; 2012. Available online: http://www. sortie-nd.org/lme/lme_R_code_tutorials.html (accessed on 2 January 2020).

45. Edwards, A.W. Likelihood, Expanded Edition; Johns Hopkins University Press: Baltimore, MD, USA, 1992.

46. Fay, P.A.; Carlisle, J.D.; Knapp, A.K.; Blair, J.M.; Collins, S.L. Productivity responses to altered rainfall patterns in a $\mathrm{C}_{4}$ dominated grassland. Oecologia 2003, 137, 245-251. [CrossRef]

47. de Aldana, B.R.V.; García Criado, B. Interannual variations of above-ground biomass and nutritional quality of Mediterranean grasslands in Western Spain over a 20-year period. Aust. J. Agric. Res. 2008, 59, 769-779. [CrossRef]

48. Elgersma, A.; Søegaard, K. Changes in nutritive value and herbage yield during extended growth intervals in grass-legume mixtures: Effects of species, maturity at harvest, and relationships between productivity and components of feed quality. Grass Forage Sci. 2018, 73, 78-93. [CrossRef]

49. Golodets, C.; Kigel, J.; Sternberg, M. Recovery of plant species composition and ecosystem function after cessation of grazing in a Mediterranean grassland. Plant Soil 2010, 329, 365-378. [CrossRef]

50. Noy-Meir, I.; Gutman, M.; Kaplan, Y. Responses of Mediterranean grassland plants to grazing and protection. J. Ecol. 1989, 77, 290-310. [CrossRef]

51. Perevolotsky, A.; Seligman, N. Role of grazing in Mediterranean rangeland ecosystems. Bioscience 1998, 48, 1007-1017. [CrossRef]

52. Cherif, E.; Doblas-Miranda, E.; Lionelloet, P.; Borrego, C.; Giorgi, F.; Iglesias, A.; Jebari, S.; Mahmoudi, E.; Moriondo, M.; Pringault, O.; et al. Climate and Environmental Change in the Mediterranean Basin-Current Situation and Risks for the Future, First Mediterranean Assessment Report (MAR1); Chapter II Drivers of Change; UNEP/MAP: Marseille, France, 2021.

53. Tielbörger, K.; Bilton, M.C.; Metz, J.; Kigel, J.; Holzapfel, C.; Lebrija-Trejos, E.; Konsens, I.; Parag, H.A.; Sternberg, M. MiddleEastern plant communities tolerate 9 years of drought in a multi-site climate manipulation experiment. Nat. Commun. 2014, 5, 1-9. [CrossRef] [PubMed] 